\title{
FACTORS AFFECTING ENTREPRENEURIAL INTENTION LEVELS: A ROLE FOR EDUCATION
}

\author{
FRANCISCO LIÑÁN* \\ Universidad de Sevilla. Departamento Economía Aplicada I \\ Av. Ramón y Cajal, 1. 41018 - Sevilla \\ E-mail: flinan@us.es
}

JUAN C. RODRÍGUEZ-COHARD

Universidad de Jaén. Departamento Economía

Paraje de las Lagunillas, s/n. 23071 - Jaén

E-mail:jccohard@ujaen.es

JOSÉ M. RUEDA-CANTUCHE

Universidad Pablo de Olavide. Departamento Economía, Métodos Cuantitativos e Historia

Económica

Carretera de Utrera, km. 1, 41013, Sevilla

E-mail: jmruecan@upo.es

\section{ABSTRACT}

A considerable agreement exists about the importance of promoting entrepreneurship to stimulate economic development and employment generation. In particular, entrepreneurship education has been considered one of the key instruments to increase the entrepreneurial attitudes of both potential and nascent entrepreneurs. Nevertheless, the factors that determine the individual's decision to start a venture are still not completely clear. Cognitive approaches have attracted considerable interest recently. But the explaining capacity of personality traits or demographic characteristics is still considered. Therefore, there is a need to clarify which elements play the most influential role in shaping the personal decision to start a firm.

This paper tries to contribute to filling this gap by providing empirically-based suggestions for the design of improved entrepreneurship education initiatives. The empirical analysis is based on two essential elements: firstly, an already validated instrument (EIQ); secondly, a statistical method (factor-regression procedure) which is not dependent on any theoretical approach. It uses all the information collected through the questionnaire items, selecting them solely based on their capacity to explain the dependent variable.

Results will allow the design of more effective education initiatives. They suggest that personal attitude and perceived behavioural control are the most relevant factors explaining entrepreneurial intentions. Thus, based on these results, a number of considerations about the most effective role of education in promoting and developing attitudes and intentions towards entrepreneurship are considered. Besides, the EIQ could be used as an evaluation instrument for entrepreneurial education programmes.

KEYWORDS: Entrepreneurship, entrepreneurial intention, entrepreneurial intention questionnaire, entrepreneurial education.

\footnotetext{
* Corresponding author: flinan@us.es; tel.: +34.954554487; fax: +34.954551636.
} 
JEL CODES: M13, C21 


\section{FACTORS AFFECTING ENTREPRENEURIAL INTENTION LEVELS: A ROLE FOR EDUCATION}

\section{Introduction}

A relevant role is generally assigned nowadays to entrepreneurship in promoting economic activity (European Commission 2003). Territories with higher increases on entrepreneurial initiative indexes tend to show a greater fall in unemployment levels (Audretsch 2002). However, the entrepreneurial resource is scarce. In 2001, less than 10 percent of the OECD adult population was starting a new venture (Nolan 2003). Therefore, a considerable agreement exists about the importance of promoting entrepreneurship to stimulate economic development and employment generation (Mitra 2008).

In particular, the role of entrepreneurship education has been called for as one of the key instruments to increase the entrepreneurial attitudes of people (Potter 2008). Thus, educational initiatives have been considered as highly promising to increase the supply of potential entrepreneurs (that is to say, making more people aware and interested on this career option) and of nascent entrepreneurs (making more people try to start a new venture).

However, there is a lack of agreement on the variables that determine the individual's decision to start a venture. Cognitive approaches have attracted considerable interest recently (Baron 2004; Krueger 2003). Among them, much attention has been paid to the entrepreneurial intention (Autio et al. 2001; Kolvereid 1996). But the explaining capacity of personality traits or demographic characteristics is still considered (Mazzarol et al. 1999; Rauch and Frese 2007; Wagner and Sternberg 2004). Therefore, there is a need to clarify which elements play the most influential role in shaping the personal decision to start a firm. This would allow the design of more effective education initiatives. 
In this sense, the present research tries to contribute to filling this gap by providing empirically-based suggestions for the design of improved entrepreneurship education initiatives. Thus, the empirical analysis is based on two essential elements:

- Firstly, a questionnaire has been built that integrates together a wide set of variables considered by different research threads as explaining entrepreneurial intention and behaviour.

- Secondly, the statistical method used (factor-regression procedure) has the advantage of not being dependent on any theoretical approach. That is, it uses all the information collected through the questionnaire items, grouping them in homogeneous factors and finally, selecting them solely based on their capacity to explain the dependent variable.

Thus, the main and novel contribution of this paper is helping determine, through an empirical data-based analysis, which variables are preponderant in determining the entrepreneurial intention and, starting from that, proposing the contents and pedagogies that may enhance these elements more effectively.

We use entrepreneurial intention as the dependent variable, since intention is considered the single best predictor of behaviour (Ajzen 1991). The questionnaire used has been developed and validated previously by Liñán and Chen (2009). In this paper, we test it on a representative sample of final-year university students.

Results suggest that personal attitude and perceived behavioural control are the two most relevant factors explaining the entrepreneurial intention. Thus, based on these results, a number of considerations about the most effective role of education in promoting and developing attitudes and intentions towards entrepreneurship are considered.

This paper has been structured in seven parts. After this introduction, the second section presents the relevant theory considered in the study. The third section describes the empirical analysis carried out. The fourth part presents the results obtained. After that, section five 
considers the role of entrepreneurial education and the implications derived from the analysis. Finally, the paper ends with a discussion and a conclusion sections.

\section{Entrepreneurial intention model}

In this section, we focus on the decision to become an entrepreneur. In this respect, methodologies used have been changing over the years (Gartner 1985, 1989; Rauch and Frese 2007). Initially, authors looked for the existence of certain personality traits that could be associated with the entrepreneurial activity, such as need for achievement (McClelland 1961). Later on, other works have analysed the importance of different characteristics such as age, gender, origin, religion, level of studies, labour experience, etc. (Reynolds, Storey and Westhead 1994; Storey 1994), which are usually called "demographic" variables (Robinson et al. 1991). Both lines of analysis have allowed the identification of significant relationships among certain traits or demographic characteristics of the individual, and the fulfilment of entrepreneurial behaviours. However, the predictive capacity has been very limited (Reynolds 1997). On the theoretical side, many authors have criticized those approaches (Ajzen 1991; Gartner 1989; Santos and Liñán 2007; Shapero and Sokol 1982; Veciana, Aponte and Urbano 2005), so much for their methodological and conceptual limitations as for their low explanatory capacity.

Gartner (1985) argued that entrepreneurs constitute a highly heterogeneous group of people that defies a common definition and, therefore, common predictors; in other words, an “average entrepreneur' does not exist and, therefore, an average personality profile of entrepreneurs cannot be determined. However, Rauch and Frese (2007) suggest that some specific traits may be linked to certain entrepreneurial tasks.

From a third perspective, since the decision to become an entrepreneur may be plausibly considered as voluntary and conscious (Krueger, Reilly and Carsrud 2000), it seems 
reasonable to analyze how that decision is taken. In this sense, the entrepreneurial intention would be a previous and determinant element towards performing entrepreneurial behaviours (Fayolle and DeGeorge 2006; Kolvereid 1996). In turn, the intention of carrying out a given behaviour will depend on the person's attitudes towards that behaviour (Ajzen 1991). More favourable attitudes would make more feasible the intention of carrying it out, and the other way round. In this sense, this "attitude approach" would be preferable to those used traditionally in the analysis of the entrepreneur, such as the traits or the demographic approaches (Krueger, Reilly and Carsrud 2000; Robinson et al. 1991). Thus, attitudes would measure the extent to which an individual values positively or negatively some behaviour (Liñán 2004).

Although not without debate, entrepreneurship -or entrepreneurial behaviour- could be defined as the discovery, evaluation and exploitation of an opportunity (Shane and Venkataraman 2000). This behaviour would be best predicted by the entrepreneurial intention. The latter, in turn, could be defined as the self-acknowledged conviction by a person that they intend to set up a new business venture and consciously plan to do so at some point in the future (Thompson 2009). In this paper, two contributions will be specially considered as a reference, due to their influence on recent research: In the first place, the theory of the "entrepreneurial event" (Shapero and Sokol 1982) and, secondly, the more structured theory of "planned behaviour" (Ajzen 1991). Both models present a high level of mutual compatibility (Krueger et al. 2000). Therefore, our work starts from an integration of both.

The entrepreneurial event theory considers firm creation as the result of the interaction among contextual factors, which would act through their influence on the individual's perceptions. The consideration of the entrepreneurial option would take place as a consequence of some external change -a precipitating event (Peterman and Kennedy 2003). People's answers to that external event will depend on their perceptions about the available alternatives. There are two basic kinds of perceptions: 
- Perceived desirability refers to the degree to which he/she feels attraction for a given behaviour (to become an entrepreneur).

- Perceived feasibility is defined as the degree to which people consider themselves personally able to carry out certain behaviour. The presence of role models, mentors or partners would be a decisive element in establishing the individual's entrepreneurial feasibility level.

In turn, both types of perceptions are determined by cultural and social factors, through their influence on the individual's values system (Shapero and Sokol 1982). Therefore, external circumstances would not determine firm-creation behaviours directly, but rather they would be the result of the (conscious or unconscious) analysis carried out by the person about the desirability and feasibility of the different possible alternatives in that situation.

Along the same line, but much more detailed, Ajzen (1991) develops a psychological model of "planned behaviour". It is a theory that may be applied to nearly all voluntary behaviours and it provides quite good results in very diverse fields, including the choice of professional career (Ajzen 2001; Kolvereid 1996). According to it, a narrow relationship would exist between the intention to be an entrepreneur, and its effective performance. Intention becomes the fundamental element towards explaining behaviour. It indicates the effort that the person will make to carry out that entrepreneurial behaviour (Liñán 2004). And so, it captures the three motivational factors that influence behaviour, which are the following (Ajzen 1991):

- Perceived behavioural control would be defined as the perception of the easiness or difficulty in the fulfilment of the behaviour of interest (becoming an entrepreneur). It is, therefore, a concept quite similar to perceived self-efficacy (Bandura 1997). In the same way, it is also very similar to Shapero and Sokol (1982)'s vision about perceived feasibility. In all three instances, the important thing is the sense of capacity regarding the fulfilment of firm creation behaviours. 
- Attitude towards the behaviour refers to the degree to which the individual holds a positive or negative personal valuation about being an entrepreneur.

- Perceived social norms would measure the perceived social pressure to carry out -or not to carry out- that entrepreneurial behaviour.

These three elements would constitute the explanatory variables of intention. Their relative contribution to the configuration of intention is not established in the model, as it may change from case to case. In particular, in the sixteen empirical works analyzed by Ajzen (1991), social norms tended to contribute very weakly to the intention of carrying out different behaviours. Finally, the model assumes the existence of interactions among the three explanatory elements.

If we compare these explanatory variables with those considered by Shapero and Sokol (1982), we can see that perceived feasibility -as it has been mentioned above- corresponds quite well with perceived behavioural control. On the other hand, the willingness to carry out entrepreneurial behaviours (perceived desirability) could be understood as composed by the personal attitude and perceived social norms. In this sense, it may be remembered that Shapero and Sokol (1982) considered desirability as a result of social and cultural influences.

\section{Insert Figure 1 around here}

Nevertheless, the adaptation of TPB to study entrepreneurial behaviour is not without criticism. Brännback, Krueger, Carsrud, Kickul, \& Elfving (2007) argue that start-up is a complex behaviour not completely under the control of the would-be entrepreneur. Similarly, some studies have found that social norm is not always significant in explaining entrepreneurial intention (Autio et al. 2001).

On the other hand, authors have identified several variables that may also explain entrepreneurial intention and behaviour. In this sense, some demographic characteristics, as 
gender (Minniti and Nardone 2007), age (Levesque and Minniti 2006) or labour experience (Cooper and Park 2008) have been found to play a role. Similarly, the existence of role models within the family is often mentioned (Matthews and Moser 1996).

The reasons to start-up are also found to differ widely (Birley and Westhead 1994). Some of these reasons relate to the desired size of the new firm. In this sense, the entrepreneurial orientation construct may also play a role in the decision to start-up (Gatewood, Shaver and Gartner 1995; Lumpkin and Dess 1996).

More recently, some research have also considered a subjectivist theory of entrepreneurship that focuses on individuals, their knowledge, resources and skills, and the processes of discovery and creativity, which constitute the heart of entrepreneurship (Kor, Mahoney and Michael 2007). In this view, the entrepreneurs' personal knowledge significantly influences the venture creation decision. Thus, knowledge about the institutional environment for start-up may play a relevant role in the configuration of entrepreneurial intentions (Luthje and Franke 2003). In general, greater knowledge of the entrepreneurial institutional framework will also directly provide a greater awareness about the existence of that professional career option, and will make the intention to become an entrepreneur more credible.

Therefore, although intention models seem to prevail in recent entrepreneurship research, different authors point to the relevance of a number of additional variables. The empirical analysis that follows will try to shed some light on the relative importance of all these variables in explaining entrepreneurial intention. 


\section{Empirical Analysis}

The empirical analysis performed here is original in the sense that it tries to let data decide which of the variables identified in the theoretical literature above exerts a stronger influence on the intention to start-up

The detailed process of construction and validation of the Entrepreneurial Intention Questionnaire (EIQ) used here has been explained by Liñán and Chen (2009). It has been carefully cross-checked following Kolvereid (1996), Krueger et al. (2000) and Veciana et al. (2005). Along the whole construction and design process, Ajzen's work has been carefully revised to solve any discrepancies (Ajzen 1991, 2001, 2002). The EIQ is included in the Appendix.

Besides, items measuring demographic characteristics, the knowledge of a role-model, knowledge of the entrepreneurial institutional framework and entrepreneurial orientation have also been included to test their possible influence on intention. Respondents were also asked if they personally knew an entrepreneur and their perceptions about how good these entrepreneurs are. As Scherer et al. (1991) pointed out, having access to role models is one key element in explaining entrepreneurship. However, they consider that knowledge alone is not enough. It has to be completed with the evaluation made about how successful those entrepreneurs are. In this paper, interviewees' evaluations of their role models have been included in the analysis together with demographic variables, in order to explain their effects on the entrepreneurial intention model.

Whenever possible, items have been built as 7-point likert-type scales. In particular, this has been true for the part of the EIQ measuring those latent variables that are crucial for the entrepreneurial intention model (see Figure 1): i.e., knowledge of the entrepreneurial institutional framework (entrepreneurial knowledge), personal attitude, social norms, selfefficacy and intention. The EIQ has been divided in ten sections (see appendix for details). Sections three to six corresponds with the elements in the entrepreneurial intention model and 
they include only one yes/no question for comparison purposes, which is the following: "Have you ever seriously considered becoming an entrepreneur?" as similar items like this one have been already used by Krueger et al (2000), Veciana et al. (2005) and others, its inclusion in the EIQ would allow establishing comparisons.

A sample of 354 final-year undergraduate students from Business and Economic Sciences was used for the empirical analysis. Business students represent $69.21 \%$ and the rest corresponds to Economics degree. They come from the two universities in Seville (Spain). Pablo Olavide University provides only 31 students, whereas the remaining 323 are from the University of Seville. This is because the former university was founded in the mid 1990s and it is still notably smaller. $55 \%$ of respondents are female, while the average age is 23.7 years old.

There are two main reasons why such a sample may be selected. Firstly, last-year students are about to face their professional career choice and secondly, these students belong to the segment of the population with empirically highest entrepreneurial inclination, according to Reynolds, Bygrave, Autio and Hay (2002). That is, those individuals between 25 and 34 years old with high level of education tend to show a greater propensity towards entrepreneurship.

\section{Factor-Regression procedure (FR procedure)}

The empirical procedure developed in this paper can be defined as a mixture of factor analysis and regression. SPSS is the statistical software used for factor analysis and Econometric Views for regressions. The first step consists of carrying out a factor analysis ${ }^{\dagger}$ with the aim of distinguishing all different underlying factors that may be explaining response patterns. Then, a regression analysis is estimated including the entrepreneurial intention factor as the explained variable and the rest of factors as explanatory variables. The regression is

\footnotetext{
${ }^{\dagger}$ According to Pardo and Ruiz (2002), factor analysis has been carried out using the main axes factorization method for extraction and the regression method for estimating the values for each factor, with a promax rotation.
} 
tested to solve, if that would be the case, heteroscedasticity, multicollinearity and autocorrelation problems.

This technique has the advantage of not being theory-dependent. That is, the factors that emerge from the data are used to explain the dependent variable. As a result, some of the explanatory variables may not be significant at a $95 \%$ confidence level, so they would be removed from the model. Once the regression model is adjusted, the underlying questions of the remaining factors are again included in a second step factor analysis, where a new grouped factors version is provided. Once more, these factors are related through a new regression model, and so on.

Hence, the final result would be a model which can explain how certain factors may influence the entrepreneurial intention. This Factor-Regression procedure is, then, clearly data-based, since items are grouped in factors emerged from response patterns. Items are not forced into any specific construct by any theoretical argument.

The final results will then be compared with the theoretical contributions to check whether they are meaningful and correspond to any specific theory. In this sense, as different measures have been used to evaluate each explaining variable, and some additional variables have also been included (especially those related to entrepreneurial orientation), there is a risk of finding factors with no easy interpretation. Nevertheless, as it is shown later, the final factors are fortunately found to be closely related to the theoretical ones (see Figure 1).

\section{Results}

The first factor analysis is performed with just 313 individuals due to non-answered questions. A total of 69 items are included, with the following break up: (a) Entrepreneurial knowledge (11 items in 3 groups); (b) Personal attitude (11 items in 3 groups); (c) Perceived social norms (11 items in 3 groups); (d) Perceived feasibility (12 items in 2 groups); (e) 
Entrepreneurial intention ( 7 items in 2 groups); and (f) Entrepreneurial orientation (17 items in 4 groups). It yields up to 19 different factors. Then, the factor scores are saved as variables and entered into a regression analysis (see Table 1). The determination coefficient (Rsquared) of the model is 0.538 , indicating a relatively good fit.

It is interesting to remark the negativity of the three following factors: growth as a key feature for success, preference for employee positions and personal attitude to entrepreneurship. That is, individuals tending to identify growth with success do have a low start-up intention. Maybe they do not see themselves as capable of reaching a big-enough size. Similarly, a high preference to be an employee is associated with lower intention, as may be expected.

In contrast, the negative relationship between personal attitude and intention is against our a priori expectations. Our first interpretation would be that some interaction effects with other factors may explain this anomalous result. Nevertheless, it may be the case that respondents' personal views of the advantages and disadvantages of entrepreneurship is not a relevant factor explaining entrepreneurial intention. For instance, other factors such as the perceived feasibility or the perceived social norms, among others, are positively related with an entrepreneurial behaviour.

\section{Insert Table 1 around here}

The second step of the factor analysis was carried out including the remaining 10 significant factors plus the entrepreneurial intention factor. In this case, the number of observations rose to 337. The results are shown in Table 2. In contrast to the first step, personal attitude changes its sign in the expected direction, becoming positive. That is, in this case, individuals with high entrepreneurial intention have a positive attitude towards being an entrepreneur. 
The sign of the coefficients associated to growth as a key feature for success and the preference to be employee remain unchanged. Notice that planning, alliances and promoting higher formation on employees are behaviours positively related to the entrepreneurial intention. Finally, personal attitude and perceived feasibility (as theory indicated) are two of the main explanatory factors regarding entrepreneurial intention for these final-year undergraduate students.

\section{Insert Table 2 around here}

However, perceived social norms are not really significant at a 95\% confidence level, which is coherent with Ajzen (1991) and Autio et al. (2001). In this case, with 337 observations, a 0.691 determination coefficient is obtained after solving some heteroscedasticity problems using the White consistent standard errors for the estimated coefficients. No problems of multicollinearity or autocorrelation were found.

In a third step, we made another factor analysis including the remaining 6 factors plus the entrepreneurial intention factor as the explained variable. The number of observations rose to 338. The results are shown in Table 3. At this stage, the friends' approval for initiating entrepreneurial activities is not significant and therefore removed, while all the rest of factors (and their signs) remain unchanged. R-squared still rose slightly to 0.708 .

\section{Insert Table 3 around here}

Finally, a last factor analysis is carried out with the remaining 5 explanatory factors and the corresponding explained variable entrepreneurial intention. The final results are shown in Table 4. At this stage, 338 observations were used. The regression model yields a 0.708 determination coefficient, which is satisfactory. 


\section{Insert Table 4 around here}

To sum up, we find that perceived feasibility and personal attitude are positively related to the entrepreneurial intention, as the TPB indicates. Connected to this, the preference to be employee is negatively related to intention, possibliy indicating that respondents tend to see these two options as alternative ones. Our results, therefore, tend to support the superiority of TPB with respect to other approaches to explaining the entrepreneurial decision. Additionally, some elements related to the entrepreneurial orientation of the individual also play a significant role. In this respect, individuals with high entrepreneurial intention give great importance to behaviours such as planning, alliances and training for employees when developing their firms. On the other hand, those with higher entrepreneurial intention do not consider growth as a key feature for success. Maybe they do not see high growth as possible, or intend to start businesses that remain small.

\section{Stimulating entrepreneurial intentions through education}

Results from our empirical study have confirmed that perceived feasibility and perceived desirability are the main factors explaining entrepreneurial intention, as many other contributions had also found before (Autio et al. 2001; Kolvereid 1996; Krueger, Reilly and Carsrud 2000; Liñán and Chen 2009; Liñán, Urbano and Guerrero forthcoming; Tkachev and Kolvereid 1999). Therefore, it may reasonably be argued that stimulating entrepreneurship through education should consider these elements.

In practice, however, it is very common for entrepreneurship education initiatives to concentrate on those participants that already have an entrepreneurial intention and have identified an opportunity (Liñán 2007). Many of these people may attempt firm creation even 
if they do not take any course. Yet, they may be lacking detailed knowledge about their closer environment (where the firm would operate) and, most commonly, not know what specific steps should be taken to start a firm. In this situation, the training could be very useful and significantly increase the number of start-ups effectively attempted. This could be identified as "start-up education", and it usually concentrates on the business-plan elaboration, carrying out visits to entrepreneurs and support bodies, or taking in local relevant guest speakers (Honig 2004). The electives available at both universities in our study were of this kind.

However, when substantially increasing the levels of entrepreneurial activity is a major concern, as it is the case in Spain or, more generally, in the European Union (European Commission 2003), a wider approach to entrepreneurship education should be used. The inclusion of some awareness contents within the training would be very important. It might be integrated within the same course, or as a separate one. This latter option has been adopted by some relevant initiatives outside the university, such as the Graduate Enterprise Programme in the United Kingdom (Brown 1990) or the Entrepreneur-Service in Norway (Kalternborn 1998).

On the other hand, there is no need to limit the education programme to the start-up phase. It might be possible to implement initiatives to develop dynamic behaviours in the participants (Foley and Griffith 1998). In this sense, Gibb (1987) pointed out the importance of training contents relating not only to the pre-start-up phase, but also to the post-creation stages. With respect to this, Garavan and O'Cinneide (1994a) highlight aspects such as "managing growth" or "continuous team building".

Entrepreneurship is considered as a process where the entrepreneur interacts with his/her environment to identify an opportunity and, eventually, start a new venture. Educational interventions may act upon different elements of that process. Therefore, in Figure 2 we try to summarise the different kinds of training activities identified so far, and where they would exert their main effect. 


\section{Insert Figure 2 around here}

According to Figure 2, development of the entrepreneurial intention could allegedly be considered as the first element to be addressed. In this sense, Kent (1990) indicated that the general opinion towards entrepreneurs is not very favourable. He was referring to the United States, but this is probably even truer in Europe (European Commission 2003). Transmitting the important role entrepreneurs play in economic growth and development would help improve participants' valuation of entrepreneurship. Similarly, Fillion (1995) includes in the category of "foundations of entrepreneurship" a series of courses that could be clearly considered as entrepreneurial awareness education. In particular, besides insisting on the importance of the entrepreneur in the economy, the following contents may be highlighted: transmitting the roles and aspects of entrepreneurship, together with the problems usually faced; identifying the abilities used by entrepreneurs, making clear that they may be developed and showing some techniques to do so; and making explicit the successive steps involved in both the start-up and the firm-development processes.

Peterman and Kennedy (2003) found that participants not having much previous experience regarding entrepreneurship -and not specially positive- increased their perceived feasibility and desirability more. Fayolle, Gailly and Lassas-Clerc (2007) and Cooper and Lucas (2007), also found a similar result: those with lower initial levels of intention increased them more than the rest. There would be a rationale, then, to try to reach all those that do not even consider this option. It may very well be the case that after participating in the programme they change their minds. In this sense, helping participants make their personal objectives explicit in the short and in the long run (their "mission") and see how it may be compatible with entrepreneurship could be another very interesting exercise, which has 
already been tried out with good results (Brown 1990; Fillion 1995; Foley and Griffith 1998; Garavan and O'Cinneide 1994b).

Contents described so far would have their main effect in affecting perceived desirability and, to a lesser extent, feasibility. However, it should be noted that all other possible contents depicted in Figure 4 would also affect intentions and their antecedents (Liñán 2007). The difference, therefore, lies in their main purpose. For that reason, these contents described below should be considered as primarily pursuing the stated objective, but indirectly affecting the entrepreneurial intention of participants (Liñán 2007).

To develop opportunity recognition abilities, Epstein (1996) identified four skills to enhance creativity. DeTienne and Chandler (2004) have adapted those skills into a training model named as SEEC (securing, expanding, exposing and challenging). They offer a detailed list of activities that could be used in an opportunity-recognition course. When they tested this model, results indicated that this training model led to the identification of more opportunities and more innovative opportunities.

On the lower part of Figure 2, over the Environment/Opportunity/New Venture area, a set of measures has been included which are specifically addressed to increase the knowledge of the local business environment, developing network contacts and having the possibility to interact with local successful role models. The importance of developing local network contacts has been highlighted by a number of authors (Johannisson 1991).

However, it is possible to go further. Hartshorn and Parvin (1999) describe a training programme which includes mentoring of participants by local entrepreneurs. Each student is placed with an entrepreneur/mentor who considers the student as a kind of advisor, letting him/her take part in all business decisions made by the entrepreneur. This would be very important not only to get a closer and more accurate knowledge of what being an entrepreneur is, but also to introduce the prospective entrepreneur in the local business circles (Gibb 1998). 
Similarly, Kent (1990) suggests the utility of using "socialization" seminars for participants. Local entrepreneurs and relevant business community stakeholders are invited to participate as well. This gives participants the opportunity to know "who is who" in the local business world, to establish important contacts, to solve specific doubts that they may have, and also to reinforce-their motivation.

At the Opportunity/New Venture link, business plans are a very well known and widely used pedagogical methodology (Gorman, Hanlon and King 1997). They would not only provide an operationalization of the business opportunity (Lechner and Dowling 1998), but also serve as a legitimization of the entrepreneur. They would produce «an aura of formality and conviction often required before an individual's creation of a new organization will be taken seriously» (Honig, 2004: 260). Besides, it may reasonably be argued that increased specific knowledge and formalization of the business idea would also help increase perceived self-efficacy of the potential entrepreneur.

However, some recent studies (Carrier 2005) indicate that a course consisting only of the production of a business plan may have a negative effect on desirability. This result, if confirmed, would be strengthening the case for a wider entrepreneurship education programme, including some or all of the contents described in this section as a complement to the business planning.

Finally, an additional element that could be also included in entrepreneurship education would refer to the development of dynamic behaviours once the firm is in operation. If these contents are integrated, we would be talking of "education for entrepreneurial dynamism" or entrepreneurial quality (Santos and Liñán 2007). Some examples that could be considered here have been described by Garavan and O'Cinneide (1994b), and they include teaching on how to manage growth and its implications for the entrepreneur's time, the firm's structure and functioning, financing requirements, and so on. Similarly, the need for the entrepreneurial 
team to be continuously re-built to adapt to new situations would also be included, together with motivation of human resources and leadership.

\section{Discussion}

Our point of departure is the evident and relevant role that entrepreneurs play in economic growth and development. Thus, higher start-up rates will contribute to increased economic prosperity. In particular, we consider the role of education in promoting entrepreneurship, based on the idea that the entrepreneurial intention is one of the key elements in explaining firm-creation activity.

This paper has tried to contribute to clarifying the still existing debate about the different theoretical variables that determine the decision to start-up. Thus, it have started from an entrepreneurial intention model, built as an integration of Shapero and Sokol's (1982) theory of the "precipitating event" and Ajzen's (1991) theory of "planned behaviour". This model has been tested through a combination of factor analysis and regression. The variables included in the analysis represent different ways to measure each of the antecedents of entrepreneurial intention. Besides, the questionnaire has been built to measure not only intention-model variables, but also others highlighted by different theoretical strands. The factor-regression procedure has offered a final result in which five significant explaining variables were left.

In our opinion, the most important thing to be learned from this empirical analysis is that the start-up decision depends not only on perceived feasibility and desirability, as traditional intention models state, but also on the "entrepreneurial orientation" of the individual. From the point of view of education, it means that entrepreneurial training needs to consider, not only increasing perceived feasibility and desirability, but also the concept of entrepreneurship, the role of the entrepreneur and the development of the venture after start-up. 
In particular, with respect to the entrepreneurial intention model, perceived feasibility and personal attitude towards entrepreneurship were significant and with the expected signs. The other two elements of the entrepreneurial intention model (Figure 1) were dropped from the analysis at different stages. In the case of perceived social norms, Ajzen (1991) found that this is frequently the weakest element and it has been non-significant in a number of different studies which applied the theory of "planned behaviour" to various actions. Regarding knowledge of the entrepreneurial institutional framework (entrepreneurial knowledge), this element has been considered by some authors (Kor, Mahoney and Michael 2007; Luthje and Franke 2003). The analysis carried out does not support its inclusion. As a possible explanation, it may be argued that it has no direct effect on intention, but an indirect effect over the antecedents (notably feasibility). Liñán (2008) offers some evidence in this respect. Alternatively, this result may have to do with the limitations of the study (see below). Since it has been tested only on one socially homogeneous sample, it may be the case that their levels of "social norms" and "entrepreneurial knowledge" are too similar to become significant in the analysis.

The negative coefficient of the preference to be an employee was expected. It means that a lower level of this variable tend to be associated with higher entrepreneurial intention. However, it is interesting to note that the correlation of the preference to be employee with personal attitude is negative and significant (-0.40), but not so high as some would expect. Besides, no multicollinearity problems were found. Consequently, in our opinion, these two factors cannot be seen as exact opposites, in line with the opinion of Kolvereid and Isaksen (2006).

Additionally, the entrepreneurial orientation of individuals (their conception of what is like to be an entrepreneur and how to make the venture survive and thrive) also affect the level of intention. In our opinion, this is an indication that the start-up decision is the result of 
complex mental processes and several elements are involved. Up to know, this has been largely ignored when designing and implementing educational initiatives.

Relevant implications have been derived from these results with regard to entrepreneurship education. In the first place, as Carrier (2005) and Honig (2004) suggest, the business plan course which is most often offered as entrepreneurial education is not enough. It may be useful to increase feasibility perceptions, but will not affect desirability. This latter element is also essential if we want to expand the base of potential entrepreneurs in a society (Fillion 1995). That is, entrepreneurship education should not only be considered as an instrumental technique for those who already have decided to be entrepreneurs. It has to become a policy instrument to make more people aware of the entrepreneurial career option.

Similarly, both the concept of success and the strategies and behaviours to achieve it, should also be considered, not only for would-be entrepreneurs to create high-growth ventures, but also for them to increase the start-up intention. At present, only the most ambitious education initiatives consider these contents, and they are addressed to entrepreneurs with high growth potential. It is often thought that more modest programmes for small-scale entrepreneurs should not worry about this. But results of this paper indicate the opposite. Every course should consider contents such as team-building, managing entrepreneur's time or leadership (Garavan and O'Cinneide 1994a).

In this sense, the available offer of entrepreneurship education at the two universities analysed is clearly insufficient. They concentrate on the business plan elaboration, without developing any other of the skills summarised in Figure 2. Only at University of Seville, the "profile of Spanish entrepreneurs" course could be said to include some awareness content and some specific local knowledge. As described in the previous section, a number of initiatives are being implemented to improve the design, contents and pedagogies of entrepreneurial education. Nevertheless, there is still a huge gap between a few leading 
institutions (mainly in North America, but some others worldwide) and the great majority of them providing only a very limited offer.

In this sense, the EIQ could be used as an instrument to measure the effectiveness of educational initiatives. That is, if the course is effective, the values of the relevant variables (attitude, perceived control, social norms, concept of success or entrepreneurial orientation) should be increased for participants in the training programme. A pre-course and post-course measure could serve to evaluate it. What skills or perceptions have and have not been increased? Which students get the most from the course? Which of them do not change their perceptions? The answer to these questions would offer very relevant information on how to improve the training programme.

Additionally, if entrepreneurial education is introduced into the primary and/or secondary schools at a general level, as Finland and some other countries have done, the use of the EIQ in these courses could offer a widespread assessment of youth's perceptions about entrepreneurship. Such a comprehensive survey would offer, not only suggestions to improve the course contents, but also interesting information for policy-makers about the opinions and perceptions of future would-be entrepreneurs.

Nevertheless, this research is not without some limitations. Firstly, it has been carried out on a sample of final-year students from a single town in Spain. Since conclusions derived aim at being generalized, the study should be replicated with different samples of student and nonstudent populations. Secondly, although the EIQ has already been validated (Liñán and Chen 2009), very few additional surveys have been performed using it. In particular, there is a need to test it cross-nationally, to confirm its validity in different cultural settings. Additionally, the instrument has not yet been specifically used as an evaluation tool for education programmes. Its applicability to this purpose will have to be established. 


\section{Conclusion}

Based on these results, if the objective of the "promoting entrepreneurship" policy is not only that already-convinced people attempts start-ups, but also increasing the number of individuals considering this option, much more ambitious education initiatives should be implemented. They should include most (if not all) of the contents suggested, such as raising awareness, firm growth and development, creativity and opportunity recognition, or knowledge of the business environment. And they should be implemented not only at the higher education level, but in the secondary and primary schools as well (Frank, Lueger and Korunka 2007).

Some of the lines of educational reform that may offer better results would be oriented to increasing self-efficacy and personal attitude, as they are the most influential elements to determine the entrepreneurial intention. In this sense, business plan courses may be an adequate tool to increase perceived self-efficacy in higher education. Other less formalized pedagogical instruments are surely needed if primary and secondary students are to be addressed. In this sense, role plays, business games, and skill-development exercises (to enhance creativity, innovativeness, networking, leadership, negotiation, etc.) would be most appropriate.

Similarly, awareness seminars, and possibly a change in the educational pedagogies towards valuing independence and autonomy of students could be very important to increase perceived attraction towards entrepreneurship.

The conclusions and recommendations offered in this paper are based on the empirical results. Since this analysis suffers from a number of limitations, the authors suggest a number of future developments they intend to follow to help consolidate the conclusions and recommendations derived above. One obvious line of research will be testing the EIQ on different additional samples from various social and cultural origins. Similarly, its use as an 
evaluation tool will be tested comparing traditional business-plan courses with more innovative and diverse educational programmes.

\section{Appendix}

\section{Entrepreneurial attitudes and intentions of university students}

\section{Questionnaire}

\section{Education and experience}

1. What degree are you studying?

2. When do you expect to finish it?
$\square$ This year (2005)
$\square$ Next year (2006)
Later (2007 or more)

3. Indicate the importance of the following reasons to choose this degree, from 1 (no important at all) to 7 (highly important).

\section{- Vocation \\ - Career opportunities \\ - Advise from family or friends}

4. Have you got labour experience (have worked or are working presently)?

If yes:

a. In what position? (if several, where stayed longer)

b. Have you been in charge of other people?

c. How much labour experience do you have? (total number of years)

d. How long is it since you left your last job position? (number of years, if still working write 0 )

e. What size was the firm in which you worked -number of employees-? (if several, where stayed longer)

\begin{tabular}{|c|c|c|c|c|c|c|}
\hline $\mathbf{1}$ & $\mathbf{2}$ & $\mathbf{3}$ & $\mathbf{4}$ & $\mathbf{5}$ & $\mathbf{6}$ & $\mathbf{7}$ \\
\hline$\square$ & $\square$ & $\square$ & $\square$ & $\square$ & $\square$ & $\square$ \\
$\square$ & $\square$ & $\square$ & $\square$ & $\square$ & $\square$ & $\square$ \\
$\square$ & $\square$ & $\square$ & $\square$ & $\square$ & $\square$ & $\square$
\end{tabular}

5. Have you ever been self-employed (independent worker or firm owner)? $\quad \square$ Yes $\square$ No If yes:

a. How long? (number of years)

b. How long is it since you left it? (number of years, if still self-employed write 0 )

\section{Entrepreneurial knowledge}

6. Do you personally know any entrepreneur? $\square$ Yes $\square$ No

If yes, indicate your relationship with them, and value the following questions from 1 (to no extent) to 7 (completely).

\section{Family}

- To what extent do you know his/her activity as an entrepreneur?

- To what extent may he/she be considered a "good entrepreneur"?

$\square$ Friend

- To what extent do you know his/her activity as an entrepreneur?

- To what extent may he/she be considered a "good entrepreneur"?

Boss / foreman

- To what extent do you know his/her activity as an entrepreneur?

- To what extent may he/she be considered a "good entrepreneur"?

$\square$ Others

- To what extent do you know his/her activity as an entrepreneur?

- To what extent may he/she be considered a "good entrepreneur"?

\begin{tabular}{|l|l|l|l|l|l|l|}
\hline 1 & 2 & 3 & 4 & 5 & 6 & 7 \\
\hline
\end{tabular}

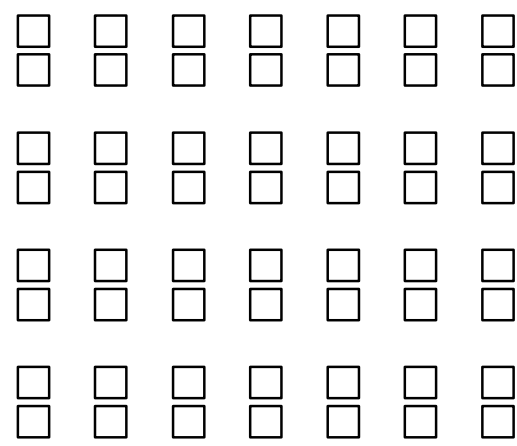


7. Indicate your level of knowledge about business associations and support bodies from 1 (absolute ignorance) to 7 (complete knowledge).

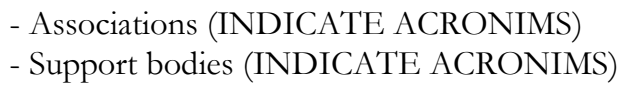

\begin{tabular}{|c|c|c|c|c|c|c|}
\hline $\mathbf{1}$ & $\mathbf{2}$ & $\mathbf{3}$ & $\mathbf{4}$ & $\mathbf{5}$ & $\mathbf{6}$ & $\mathbf{7}$ \\
\hline$\square$ & $\square$ & $\square$ & $\square$ & $\square$ & $\square$ & $\square$ \\
$\square$ & $\square$ & $\square$ & $\square$ & $\square$ & $\square$ & $\square$
\end{tabular}

8. For each of the following measures to support firm creation, indicate your level of detailed knowledge from 1 (absolute ignorance) to 7 (complete knowledge).

- Specific training for young entrepreneurs

- Loans in specially favourable terms

- Technical aid to start the business

- Business centres

- Consulting services in favourable terms

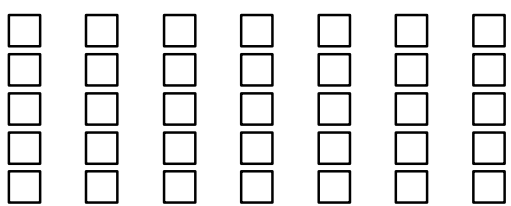

\section{Professional attraction}

9. What would you like to do immediately after finishing your degree? Value the following options from 1 (minimum preference) to 7 (maximum preference).

\footnotetext{
- Working as an employee

- Starting-up a firm

- Follow on training and preparation
}

\begin{tabular}{|c|c|c|c|c|c|c|}
\hline $\mathbf{1}$ & $\mathbf{2}$ & $\mathbf{3}$ & $\mathbf{4}$ & $\mathbf{5}$ & $\mathbf{6}$ & $\mathbf{7}$ \\
$\square$ & $\square$ & $\square$ & $\square$ & $\square$ & $\square$ & $\square$ \\
$\square$ & $\square$ & $\square$ & $\square$ & $\square$ & $\square$ & $\square$ \\
$\square$ & $\square$ & $\square$ & $\square$ & $\square$ & $\square$ & $\square$
\end{tabular}

10. In the medium and longer term, considering all advantages and disadvantages (economic, personal, social recognition, labour stability, and so on), indicate your level of attraction towards each of the following professional options from 1 (minimum attraction) to 7 (maximum attraction).

\footnotetext{
- salaried work

- liberal profession

- Entrepreneur
}

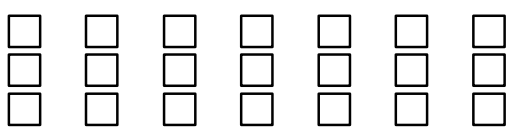

11. Indicate your level of agreement with the following sentences from 1 (total disagreement) to 7 (total agreement).

- Being an entrepreneur implies more advantages than disadvantages to me

- A career as entrepreneur is attractive for me

- If I had the opportunity and resources, I'd like to start a firm

- Being an entrepreneur would entail great satisfactions for me

- Among various options, I'd rather be an entrepreneur

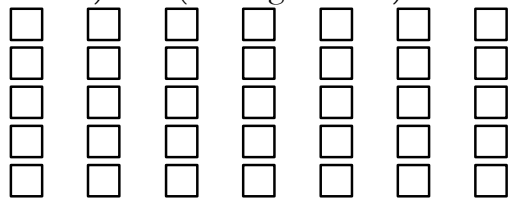

\section{Social valuation}

12. In your closest environment, do you think the entrepreneurial activity is valued worse or better than other activities and careers? Indicate from 1 (much below others) to 7 (much above others).

- In your close family

- Among your friends

- Among your colleagues and mates

\begin{tabular}{|c|c|c|c|c|c|c|}
\hline $\mathbf{1}$ & $\mathbf{2}$ & $\mathbf{3}$ & $\mathbf{4}$ & $\mathbf{5}$ & $\mathbf{6}$ & $\mathbf{7}$ \\
$\square$ & $\square$ & $\square$ & $\square$ & $\square$ & $\square$ & $\square$ \\
$\square$ & $\square$ & $\square$ & $\square$ & $\square$ & $\square$ & $\square$ \\
$\square$ & $\square$ & $\square$ & $\square$ & $\square$ & $\square$ & $\square$
\end{tabular}

13. If you decided to create a firm, people in your close environment would approve of that decision? Indicate from

1 (total disapprovement) to 7 (total approvement).

- Your close family

- Your friends

- Your colleagues and mates

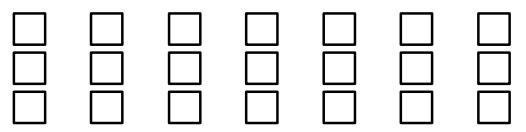

14. Indicate your level of agreement with the following sentences from 1 (total disagreement) to 7 (total agreement).

- Entrepreneurial activity clashes with the culture in my country

- The entrepreneur's role in the economy is not sufficiently recognized

- Many people consider hardly acceptable to be an entrepreneur

- Entrepreneurial activity is considered too risky to be worth while

- It is commonly thought that entrepreneurs take advantage of others

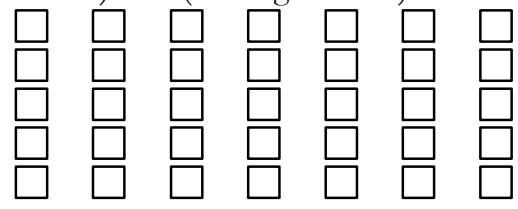

\section{Entrepreneurial capacity}

15. To what extent do you agree with the following statements regarding your entrepreneurial capacity? Value them from 1 (total disagreement) to 7 (total agreement).

- Start a firm and keep it working would be easy for me

- I'm prepared to start a viable firm

- I can control the creation process of a new firm

\begin{tabular}{|c|c|c|c|c|c|c|}
\hline $\mathbf{1}$ & 2 & 3 & 4 & 5 & 6 & 7 \\
\hline$\square$ & $\square$ & $\square$ & $\square$ & $\square$ & $\square$ & $\square$ \\
$\square$ & $\square$ & $\square$ & $\square$ & $\square$ & $\square$ & $\square$ \\
$\square$ & $\square$ & $\square$ & $\square$ & $\square$ & $\square$ & $\square$
\end{tabular}


- I know the necessary practical details to start a firm

- I know how to develop an entrepreneurial project

- If I tried to start a firm, I would have a high probability of succeeding

16. Do you think you have a satisfactory level of the following capacities to be an entrepreneur? Indicate from 1 (no capacity at all) to 7 (very high capacity).

- Opportunity recognition

- Creativity

- Problem solving

- Leadership and communication skills

- Development of knew products and services

- Networking and making professional contacts

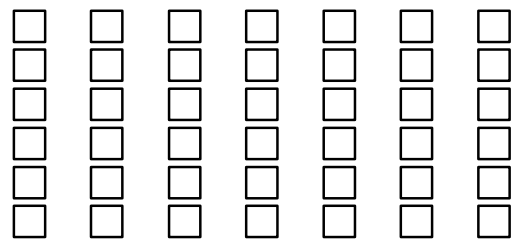

\section{Entrepreneurial intention}

17. Have you ever seriously considered becoming an entrepreneur? $\quad \square$ Yes $\square$ No

18. Indicate your level of agreement with the following statements from 1 (total disagreement) to 7 (total agreement)

- I'm ready to make anything to be an entrepreneur

- My professional goal is becoming an entrepreneur

- I will make every effort to start and run my own firm

- I'm determined to create a firm in the future

- I have very seriously thought in starting a firm

- I've got the firm intention to start a firm some day

\begin{tabular}{c|c|c|c|c|c|c} 
1 & 2 & 3 & 4 & 5 & 6 & 7 \\
$\square$ & $\square$ & $\square$ & $\square$ & $\square$ & $\square$ & $\square$ \\
$\square$ & $\square$ & $\square$ & $\square$ & $\square$ & $\square$ & $\square$ \\
$\square$ & $\square$ & $\square$ & $\square$ & $\square$ & $\square$ & $\square$ \\
$\square$ & $\square$ & $\square$ & $\square$ & $\square$ & $\square$ & $\square$ \\
$\square$ & $\square$ & $\square$ & $\square$ & $\square$ & $\square$ & $\square$ \\
$\square$ & $\square$ & $\square$ & $\square$ & $\square$ & $\square$ & $\square$
\end{tabular}

\section{Entrepreneurial objectives}

19. If you ever started a firm, what size would you like it to achieve (number of employees)?

$\square$ Self-employed $\square$ Micro-enterprise $\square$ Small enterprise $\square$ Medium enterprise $\square$ Large enterp.

(no employees) (up to 10 employees) (10 to 50 employees) (50 to 250 employees) (> 250 empls.)

20. To what extent do you consider the following results as corresponding to entrepreneurial success? Indicate from 1 (to no extent) to 7 (totally).

- Competing hard in world markets

- Reaching a high level of income

- Carrying out the kind of job you really like

- Achieving great social recognition

- Helping to solve the problems of my community

- Keeping the business alive

- Keeping a path of positive growth

\begin{tabular}{|c|c|c|c|c|c|c|}
\hline 1 & 2 & 3 & 4 & 5 & 6 & 7 \\
\hline & $\square$ & $\square$ & $\square$ & $\square$ & $\square$ & $\square$ \\
$\square$ & $\square$ & $\square$ & $\square$ & $\square$ & $\square$ & $\square$ \\
$\square$ & $\square$ & $\square$ & $\square$ & $\square$ & $\square$ & $\square$ \\
$\square$ & $\square$ & $\square$ & $\square$ & $\square$ & $\square$ & $\square$ \\
$\square$ & $\square$ & $\square$ & $\square$ & $\square$ & $\square$ & $\square$ \\
$\square$ & $\square$ & $\square$ & $\square$ & $\square$ & $\square$ & $\square$ \\
$\square$ & $\square$ & $\square$ & $\square$ & $\square$ & $\square$ & $\square$
\end{tabular}

21. With respect to the continuous development of your enterprise, how important would it be for you?

- Indicate from 1 (not important at all) to 7 (highly important)

22. To what extent would you perform the following behaviours to develop your firm? Indicate from 1 (to no extent) to 7 (to a great extent).

- Exporting a significant share of production

- Introducing regularly new products/services for your costumers

- Introducing regularly new processes or systems of production

- Developing R + D projects

- Planning the different areas of the firm with detail

- Reaching cooperation agreements or partnerships with other firms

- Offer specialized training for employees

- Enlarging your firm (personnel, premises, etc.)

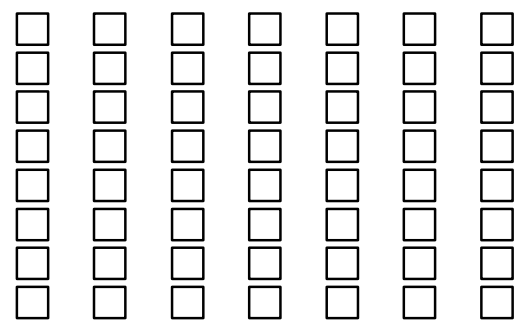

\section{Entrepreneurship education}

23. To what extent do you thing it is possible to offer entrepreneurship education courses which develop the following aspects? Indicate from 1 (not possible at all) to 7 (totally possible).

- Knowledge about the entrepreneurial environment

- Greater recognition of the entrepreneur's figure

- The preference to be an entrepreneur

- The necessary abilities to be an entrepreneur

- The intention to be an entrepreneur

\begin{tabular}{|c|c|c|c|c|c|c|}
\hline 1 & 2 & 3 & 4 & 5 & 6 & 7 \\
\hline$\square$ & $\square$ & $\square$ & $\square$ & $\square$ & $\square$ & $\square$ \\
$\square$ & $\square$ & $\square$ & $\square$ & $\square$ & $\square$ & $\square$ \\
$\square$ & $\square$ & $\square$ & $\square$ & $\square$ & $\square$ & $\square$ \\
$\square$ & $\square$ & $\square$ & $\square$ & $\square$ & $\square$ & $\square$ \\
$\square$ & $\square$ & $\square$ & $\square$ & $\square$ & $\square$ & $\square$
\end{tabular}


24. Have you taken any course or module that could be considered as entrepreneurship education?

If yes:

a. Indicate which one(s):

b. To what extent has it helped you develop any of those aspects? Indicate from 1 (to no extent) to 7 (to a great extent)

- Knowledge about the entrepreneurial environment

- Greater recognition of the entrepreneur's figure

- The preference to be an entrepreneur

- The necessary abilities to be an entrepreneur

- The intention to be an entrepreneur

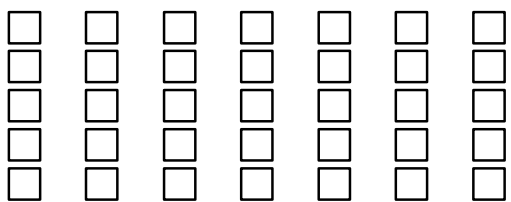

\section{Personal data}

25. Age:

26. Gender: $\square$ Male $\square$ Female

27. Place of birth: . Place of residence:

28. Number of people living in your household (including yourself):

29. What level of studies have your parents reached?

Father: $\square$ Primary $\square$ Secondary

Mother: $\square$ Primary $\square$ Secondary

$\square$ Vocational training

$\square$ Vocational training ; of them, under age.

30. What are their present occupations?

\section{Private sector \\ Public sector} employee

Father:

Mother:

employee

self-employed

or entrepreneur Retired

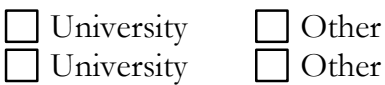

31. Roughly speaking, what is the total monthly income in your household? (adding up all revenues from any person living in the household)

$\square$ Up to $€ 500 \quad \square$ From $€ 500$ to $€ 1000 \square$ From $€ 1000$ to $€ 2000 \square$ From $€ 2000$ to $€ 4000$
$\square$ From $€ 4000$ to $€ 7000 \square$ From $€ 7000$ to $€ 10000 \square$ Over $€ 10000$

\section{Contact Data}

Filling in the following data will allow to subsequently follow-up your evolutions. Any information provided will be considered as strictly confidential, and will only be used for the aims of this research project.

Name:

Postal address:

City/town: Post Code:

e-mail:

Telephone: Mobile: 


\section{Acknowledgements}

The authors wish to thank the editors, for their guidance and support through the review process, and two anonymous referees for their comments and suggestions, which have substantially contributed to improve this final version of the paper. Of course, any errors that remain are the sole responsibility of the authors.

\section{References}

Ajzen, I. (1991). The Theory of Planned Behavior. Organizational Behavior and Human Decision Processes, 50(2), 179-211.

Ajzen, I. (2001). Nature and operation of attitudes. Annual Review of Psychology, 52, 27-58.

Ajzen, I. (2002). Perceived behavioral control, self-efficacy, locus of control, and the theory of planned behavior. Journal of Applied Social Psychology, 32(4), 665-683.

Audretsch, D. B. (2002). Entrepreneurship : determinants and policy in a European-US comparison. Boston: Kluwer Academic Publishers.

Autio, E., Keeley, R. H., Klofsten, M., Parker, G. G. C., \& Hay, M. (2001). Entrepreneurial intent among students in Scandinavia and in the USA. Enterprise and Innovation Management Studies, 2(2), 145160 .

Bandura, A. (1997). Self-efficacy: The exercise of control. New York: Freeman.

Baron, R. A. (2004). The cognitive perspective: a valuable tool for answering entrepreneurship's basic "why" questions. Journal of Business Venturing, 19(2), 221-239.

Birley, S., \& Westhead, P. (1994). A Taxonomy of Business Start-up Reasons and Their Impact on Firm Growth and Size. Journal of Business Venturing, 9(1), 7-31.

Brännback, M., Krueger, N. F., Jr., Carsrud, A. L., Kickul, J., \& Elfving, J. (2007). 'Trying' to be an Entrepreneur? A 'Goal-Specific' Challenge to the Intentions Model: SSRN.

Brown, R. (1990). Encouraging enterprise: Britain's Graduate Enterprise Program. Journal of Small Business Management, 28(4), 71-77.

Carrier, C. (2005). Pedagogical challenges in entrepreneurship education. In P. Kyrö \& C. carrier (Eds.), The dynamics of learning entrepreneurship in a cross-cultural univeristy context (pp. 136-158). Hämmeenlinna: University of Tampere.

Cooper, S. Y., \& Lucas, W. A. (2007). Developing entrepreneurial self-efficacy and intentions: lessons from two programmes. Paper presented at the Proceedings of the 52nd ICSB World Conference.

Cooper, S. Y., \& Park, J. S. (2008). The impact of 'incubator' organizations on opportunity recognition and technology innovation in new, entrepreneurial high-technology ventures. International Small Business Journal, 26(1), 27-56.

DeTienne, D. R., \& Chandler, G. N. (2004). Opportunity identification and its role in the entrepreneurial classroom: A pedagogical approach and empirical test. Academy of Management Learning and Education, 3(3), 242-257.

Epstein, R. (1996). Cognition, creativity and behaviour. Wetport (CT): Praeger.

European Commission. (2003). Green Paper - Entrepreneurship in Europe. Brussels: DG Enterprise. European Commission.

Fayolle, A., \& DeGeorge, J.-M. (2006). Attitudes, intentions, and behaviour: New approaches to evaluating entrepreneurship education. In A. Fayolle \& H. Klandt (Eds.), International Entrepreneurship Education. Issues and Newness (pp. 74-89). Cheltenham (UK): Edward Elgar.

Fayolle, A., Gailly, B., \& Lassas-Clerc, N. (2007). Towards a new methodology to assess the entrepreneurship teaching programmes. In A. Fayolle (Ed.), Handbook of research in entrepreneurship education (Vol. 1, pp. 187-197). Cheltenham: Edward Elgar.

Fillion, L. J. (1995). Entrepreneurship and management: Differing but complementary Processes. Cahier de Recherche, CETAI, HEC Montreal., 95-01.

Foley, A., \& Griffith, B. (1998). Education, training and the promotion of high quality entrepreneurs in the Republic of Ireland. In M. G. Scott, P. Rosa \& H. Klandt (Eds.), Educating entrepreneurs for wealth creation. Aldershot: Ashgate.

Frank, H., Lueger, M., \& Korunka, C. (2007). The significance of personality in business start-up intentions, start-up realization and business success. Entrepreneurship and Regional Development, 19(3), 227-251.

Garavan, T. N., \& O'Cinneide, B. (1994a). Entrepreneurship education and training programmes: a review and evaluation - Part II. Journal of European Industrial Training, 18(11), 13-21.

Garavan, T. N., \& O'Cinneide, B. (1994b). Entrepreneurship education and training programmes: a review and evaluation. Journal of European Industrial Training, 18(8), 3-12. 
Gartner, W. B. (1985). A conceptual framework for describing the phenomenon of new venture creation. Academy of Management Review, 10(4), 494-706.

Gartner, W. B. (1989). 'Who is an entrepreneur?' is the wrong question. Entrepreneurship Theory and Practice, 13(4), 47-68.

Gatewood, E. J., Shaver, K. G., \& Gartner, W. B. (1995). A Longitudinal-Study of Cognitive-Factors Influencing Start-up Behaviors and Success at Venture Creation. Journal of Business Venturing, 10(5), 371-391.

Gibb, A. A. (1987). Designing effective programmes for encouraging the business start-up process: lessons from UK experience. Journal of European Industrial Training, 11(4), 24-32.

Gibb, A. A. (1998). Entrepreneurial core capacities, competitiveness and management development in the $21 \mathrm{st}$ century. Paper presented at the IntEnt Conference, Oestrich-Winkel.

Gorman, G. G., Hanlon, D., \& King, W. (1997). Some research perspectives on entrepreneurship education, enterprise education and education for small business management. International Small Business Journal, 15, 56-77.

Hartshorn, C., \& Parvin, W. (1999). Teaching entrepreneurship: creating and implementing a naturalistic model. Paper presented at the International Conference EuroPME, Rennes.

Honig, B. (2004). Entrepreneurship education: Toward a model of contingency-based business planning. Academy of Management Learning and Education, 3(3), 258-273.

Johannisson, B. (1991). University training for entrepreneurship: Swedish approaches. Entrepreneurship and Regional Development, 3(1), 67-82.

Kalternborn, O. (1998). Entrepreneur-Service (ES) - a national project for improved local service to entrepreneurs. In M. G. Scott, P. Rosa \& H. Klandt (Eds.), Educating Entrepreneurs for Wealth Creation. Aldershot: Ashgate.

Kent, C. A. (1990). Entrepreneurship education : current developments, future directions. New York: Quorum Books.

Kolvereid, L. (1996). Prediction of employment status choice intentions. Entrepreneurship Theory and Practice, 21(1), 47-57.

Kolvereid, L., \& Isaksen, E. (2006). New business start-up and subsequent entry into self-employment. Journal of Business Venturing, 21(6), 866-885.

Kor, Y. Y., Mahoney, J. T., \& Michael, S. C. (2007). Resources, Capabilities and Entrepreneurial Perceptions Journal of Management Studies, 44(7), 1187-1212.

Krueger, N. F. (2003). The cognitive psychology of entrepreneurship. In Z. J. Acs \& D. B. Audretsch (Eds.), Handbook of entrepreneurship research: An interdisciplinary survey and introduction (pp. 105-140). London: Kluwer.

Krueger, N. F., Reilly, M. D., \& Carsrud, A. L. (2000). Competing models of entrepreneurial intentions. Journal of Business Venturing, 15(5-6), 411-432.

Lechner, C., \& Dowling, M. (1998). How to design business plan seminars? Single topic business plan courses as a focused approach. Paper presented at the IntEnt Conference, Oestrich-Winkel.

Levesque, M., \& Minniti, M. (2006). The effect of aging on entrepreneurial behavior. Journal of Business Venturing, 21(2), 177-194.

Liñán, F. (2004). Intention-based models of entrepreneurship education. Piccola Impresa / Small Business, 2004(3), 11-35.

Liñán, F. (2007). The Role of Entrepreneurship Education in the Entrepreneurial Process. In A. Fayolle (Ed.), Handbook of Research in Entrepreneurship Education (Vol. 1, pp. 230-247). Cheltenham, UK: Edward Elgar Publishing.

Liñán, F. (2008). Skill and value perceptions: how do they affect entrepreneurial intentions? International Entrepreneurship and Management Journal, 4(3), 257-272.

Liñán, F., \& Chen, Y. W. (2009). Development and cross-cultural application of a specific instrument to measure entrepreneurial intentions. Entrepreneurship Theory and Practice, 33(3), 593-617.

Liñán, F., Urbano, D., \& Guerrero, M. (forthcoming). Regional variations in entrepreneurial cognitions: Start-up intentions of university students in Spain. Entrepreneurship and Regional Development.

Lumpkin, G. T., \& Dess, G. G. (1996). Clarifying the entrepreneurial orientation construct and linking it to performance. Academy of Management Review, 21(1), 135-172.

Luthje, C., \& Franke, N. (2003). The 'making' of an entrepreneur: testing a model of entrepreneurial intent among engineering students at MIT. $R \&$ D Management, 33(2), 135-147.

Matthews, C. H., \& Moser, S. B. (1996). A longitudinal investigation of the impact of family background and gender on interest in small firm ownership. Journal of Small Business Management, 34(2), 29-43.

Mazzarol, T., Volery, T., Doss, N., \& Thein, V. (1999). Factors influencing small business start-ups. A comparison with previous research. International Journal of Entrepreneurial Behaviour \& Research, 5(2), 48-63.

McClelland, D. C. (1961). The achieving society. Princeton, N.J ; London: Van Nostrand. 
Minniti, M., \& Nardone, C. (2007). Being in someone else's shoes: the role of gender in nascent entrepreneurship. Small Business Economics, 28(2-3), 223-238.

Mitra, J. (2008). Towards an analytical framework for policy development. In J. Potter (Ed.), Entrepreneurship and Higher Education. Paris: OECD - Local Economic and Employment Development (LEED).

Nolan, A. (2003). Entrepreneurship and local economic development. Paris: OECD.

Pardo, A., \& Ruiz, M. A. (2002). SPSS 11 Guía para el análisis de datos. Madrid: McGraw-Hill.

Peterman, N. E., \& Kennedy, J. (2003). Enterprise education: Influencing students' perceptions of entrepreneurship. Entrepreneurship Theory and Practice, 28(2), 129-144.

Potter, J. (2008). Entrepreneurship and Higher Education. Paris: OECD - Local Economic and Employment Development (LEED).

Rauch, A., \& Frese, M. (2007). Let's put the person back into entrepreneurship research: A meta-analysis on the relationship between business owners' personality traits, business creation, and success. European Journal of Work and Organizational Psychology, 16(4), 353-385.

Reynolds, P. D. (1997). Who starts new firms? - Preliminary explorations of firms-in-gestation. Small Business Economics, 9(5), 449-462.

Reynolds, P. D., Storey, D. J., \& Westhead, P. (1994). Cross-national comparison of the variation in new firm rates. Regional Studies, 28, 443-456.

Reynolds, P. D., Bygrave, W., Autio, E., \& Hay, M. (2002). Global Entrepreneurship Monitor. 2002 summary report. Kansas City: Ewin Marion Kauffman Foundation.

Robinson, P. B., Stimpson, D. V., Huefner, J., \& Hunt, H. K. (1991). An attitude approach to the prediction of entrepreneurship. Entrepreneurship Theory and Practice, 15(4), 13-31.

Santos, F. J., \& Liñán, F. (2007). Measuring entrepreneurial quality in southern Europe. International Entrepreneurship and Management Journal, 3(1), 87-107.

Shane, S., \& Venkataraman, S. (2000). The promise of entrepreneurship as a field of research. Academy of Management Review, 25(1), 217-226.

Shapero, A., \& Sokol, L. (1982). Social dimensions of entrepreneurship. In C. A. Kent, D. L. Sexton \& K. H. Vesper (Eds.), Encyclopedia of entrepreneurship (pp. 72-90). Englewood Cliffs (NJ): Prentice Hall.

Storey, D. J. (1994). Understanding the small business sector. London: Routledge.

Thompson, E. R. (2009). Individual entrepreneurial intent: construct clarification and development of an internationally reliable metric. Entrepreneurship Theory and Practice, 33(3), 669-694.

Tkachev, A., \& Kolvereid, L. (1999). Self-employment intentions among Russian students. Entrepreneurship and Regional Development, 11(3), 269-280.

Veciana, J. M., Aponte, M., \& Urbano, D. (2005). University students' attitudes towards entrepreneurship: a two countries comparison. International Entrepreneurship and Management Journal, 1(2), 165-182.

Wagner, J., \& Sternberg, R. (2004). Start-up activities, individual characteristics, and the regional milieu: Lessons for entrepreneurship support policies from German micro data. Annals of Regional Science, 38(2), 219-240. 
Figure 1

Entrepreneurial intention model

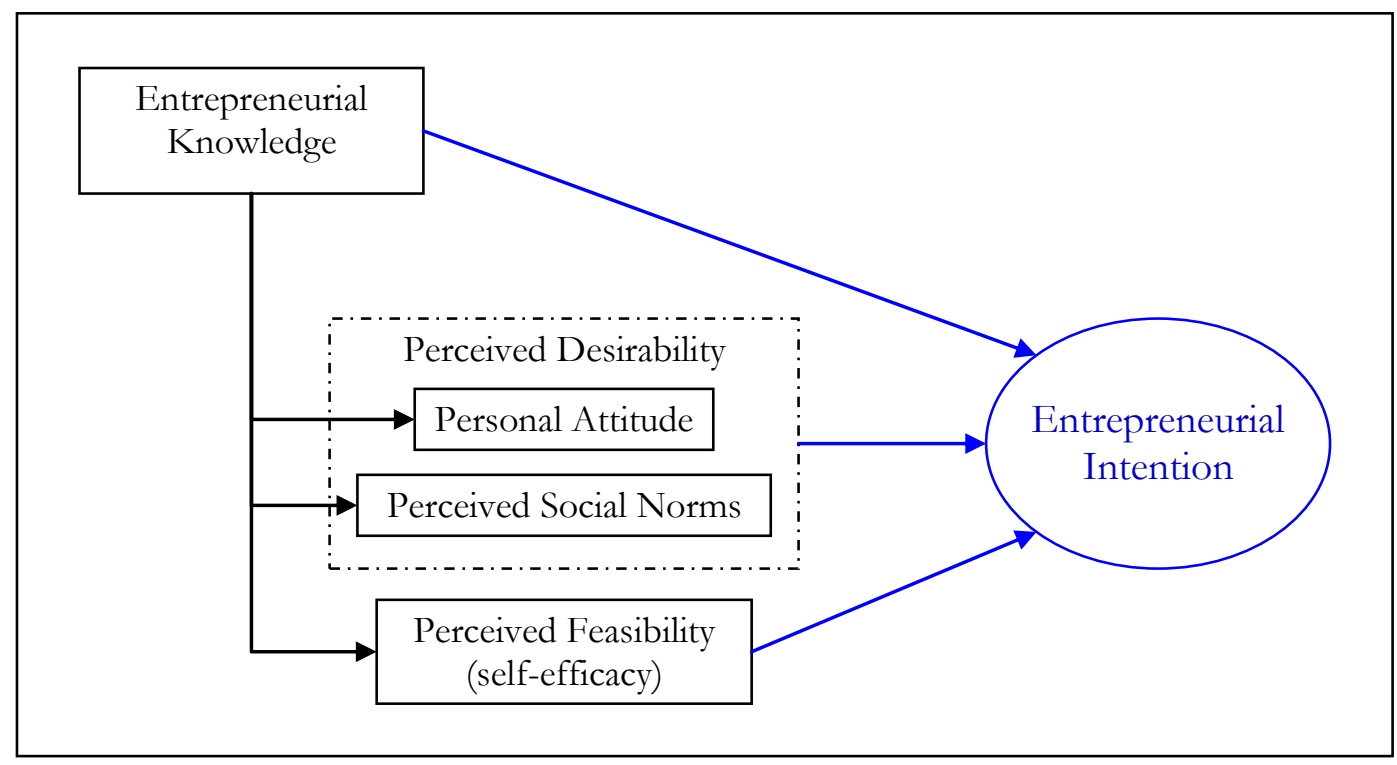

Source: Liñán (2004: 15), Figure 2. 
Figure 2.

Role of entrepreneurship education in the entrepreneurial process

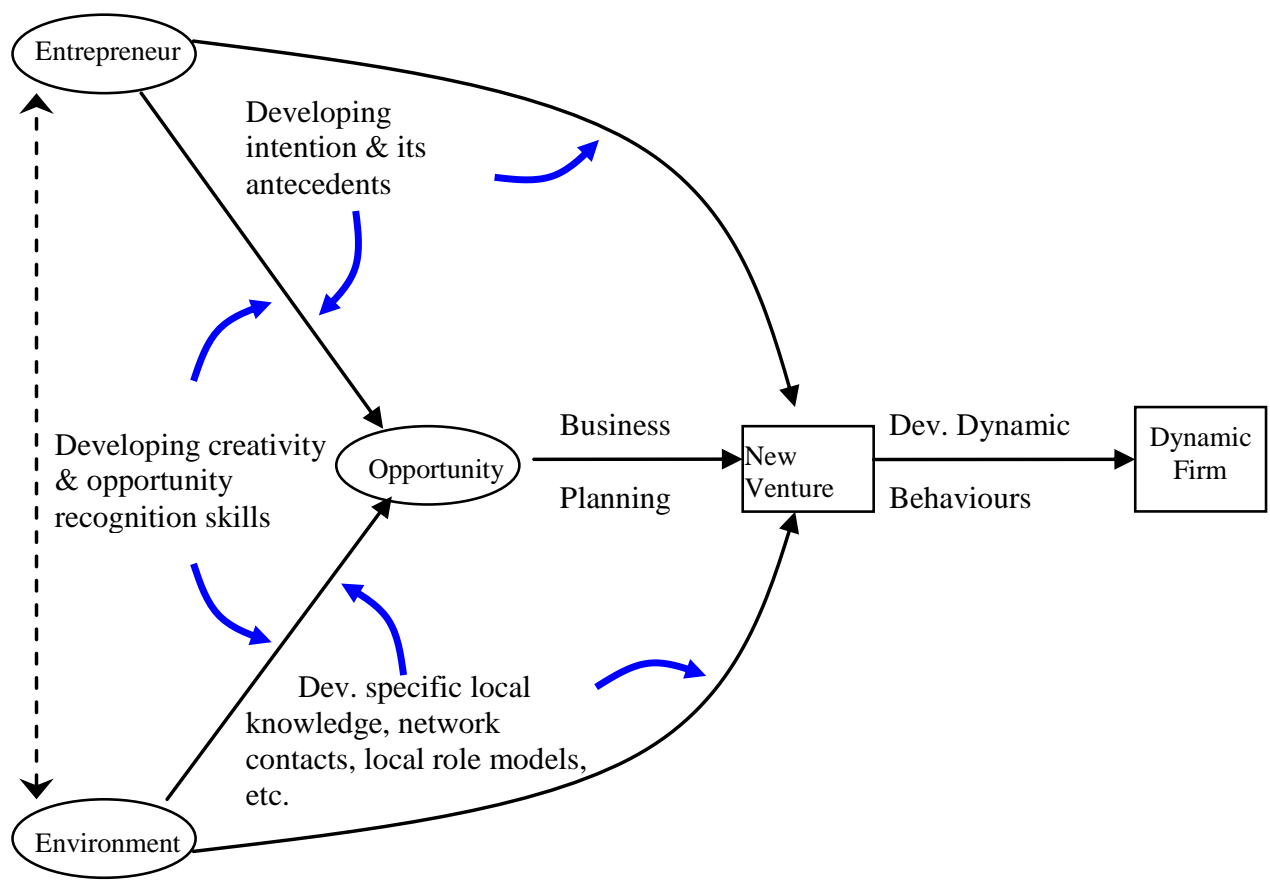

Source: Liñán (2007, p. 241, Figure 13.4) 
Table 1

Factor-regression procedure: First regression

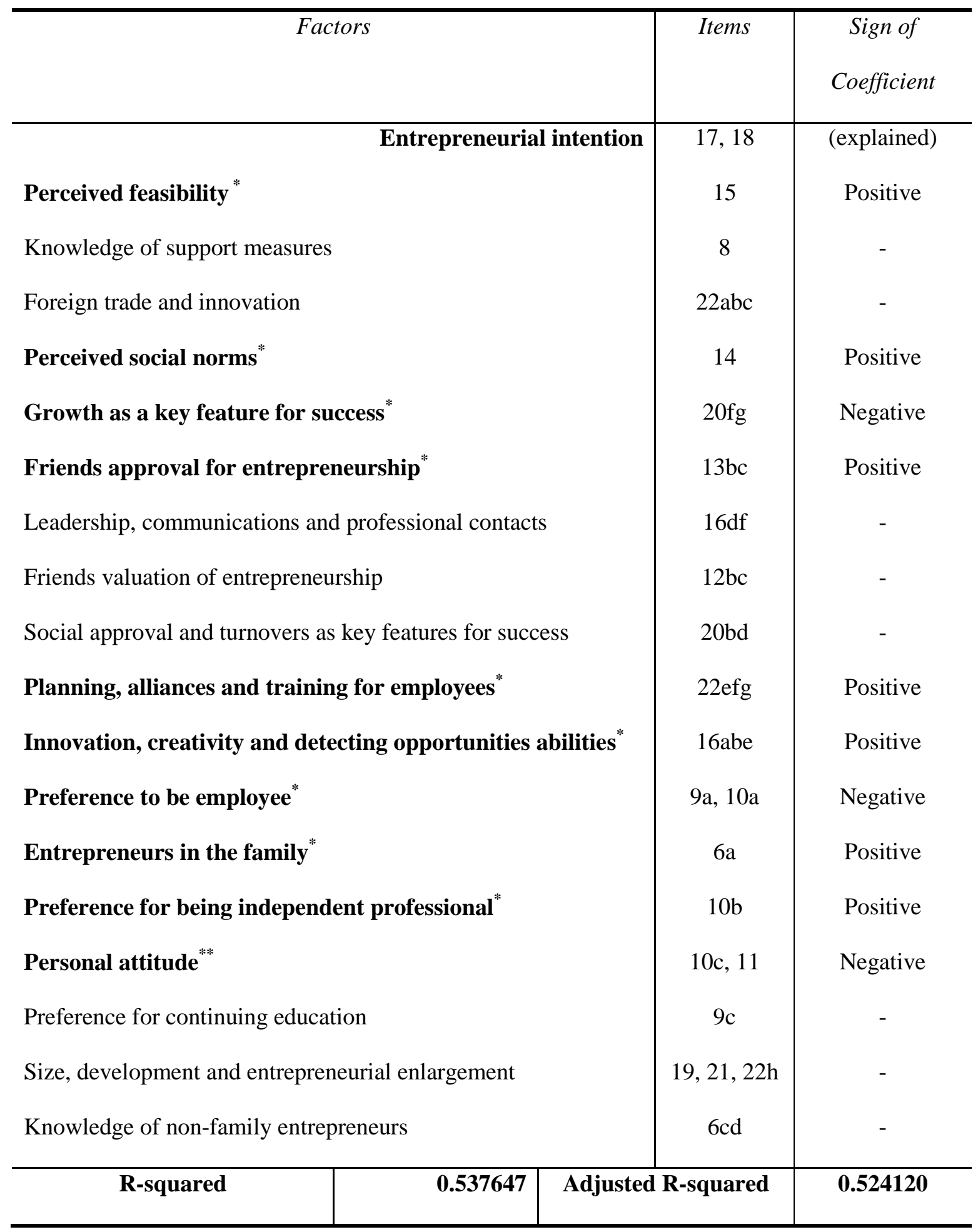

* Significant at a 95\% confidence level.

** Significant at a maximum $93 \%$ confidence level. 
Table 2

Factor-regression procedure: Second regression

\begin{tabular}{|c|c|c|c|}
\hline \multicolumn{2}{|l|}{ Factors } & Items & $\begin{array}{c}\text { Sign of } \\
\text { Coefficien }\end{array}$ \\
\hline \multicolumn{2}{|c|}{ Entrepreneurial intention } & 17,18 & (explained) \\
\hline \multicolumn{2}{|l|}{ Perceived feasibility ${ }^{*}$} & 15 & Positive \\
\hline \multicolumn{2}{|l|}{ Personal Attitude * } & $10 \mathrm{bc}, 11$ & Positive \\
\hline \multicolumn{2}{|l|}{ Perceived social norms } & 14 & - \\
\hline \multicolumn{2}{|l|}{ Planning, alliances and training for employees* } & $22 \mathrm{efg}$ & Positive \\
\hline \multicolumn{2}{|l|}{ Friends approval for entrepreneurship" } & $13 \mathrm{bc}$ & Negative \\
\hline \multicolumn{2}{|l|}{ Growth as a key feature for success* } & $20 f g$ & Negative \\
\hline \multicolumn{2}{|l|}{ Innovation, creativity and detecting opportunities abilities } & 16abe & - \\
\hline \multicolumn{2}{|l|}{ Preference to be employee ${ }^{*}$} & $9 a, 10 a$ & Negative \\
\hline R-squared & Adjusted & -squared & 0.686588 \\
\hline
\end{tabular}

* Significant at a 95\% confidence level.

** Significant at a maximum $93 \%$ confidence level. 
Table 3

Factor-regression procedure: Third regression

\begin{tabular}{|c|c|c|c|}
\hline \multicolumn{2}{|l|}{ Factors } & Items & Sign of \\
\hline \multicolumn{2}{|c|}{ Entrepreneurial intention } & 17,18 & (explained) \\
\hline \multicolumn{2}{|l|}{ Perceived feasibility ${ }^{*}$} & 15 & Positive \\
\hline \multicolumn{2}{|l|}{ Personal Attitude * } & $10 \mathrm{bc}, 11$ & Positive \\
\hline \multicolumn{2}{|l|}{ Planning, alliances and training for employees ${ }^{*}$} & $22 \mathrm{efg}$ & Positive \\
\hline \multicolumn{2}{|l|}{ Friends approval for entrepreneurship } & $13 \mathrm{bc}$ & - \\
\hline \multicolumn{2}{|l|}{ Growth as a key feature for success* } & $20 f g$ & Negative \\
\hline \multicolumn{2}{|l|}{ Preference to be employee* } & $9 \mathrm{a}, 10 \mathrm{a}$ & Negative \\
\hline R-squared & Adjusted & -squared & 0.703986 \\
\hline
\end{tabular}

* Significant at a 95\% confidence level. 
Table 4

Factor-regression procedure: Fourth regression

\begin{tabular}{|c|c|c|c|}
\hline \multicolumn{2}{|l|}{ Factors } & Items & $\begin{array}{c}\text { Sign of } \\
\text { Coefficient }\end{array}$ \\
\hline \multicolumn{2}{|c|}{ Entrepreneurial intention } & 17,18 & (explained) \\
\hline Perceived feasibility ${ }^{*}$ & & 15 & Positive \\
\hline Personal Attitude * & & $10 \mathrm{bc}, 11$ & Positive \\
\hline Planning, alliances and training for employees* & & $22 \mathrm{efg}$ & Positive \\
\hline Growth as a key feature for success" & & $20 f g$ & Negative \\
\hline Preference to be employee* $^{*}$ & & $9 \mathrm{a}, 10 \mathrm{a}$ & Negative \\
\hline R-squared & Adjusted & -squared & 0.704196 \\
\hline
\end{tabular}

* Significant at a 95\% confidence level. 